\title{
HHV8 ORF59 Gene
}

National Cancer Institute

\section{Source}

National Cancer Institute. HHV8 ORF59 Gene. NCI Thesaurus. Code C114506.

HHV8 ORF59, which encodes DNA polymerase processivity factor protein, plays a role in viral DNA replication. 